\title{
少子化とこども病院
}

長野県立こども病院

原田 順和

\section{Declining Birth Rate and Stand-Alone Children's Hospital}

\author{
Yorikazu Harada \\ Nagano Children's Hospital, Nagano, Japan
}

少子化による人口減少が叫ばれてから久しい.わが国では, 1970 年代以降の少子化の影響により, 人口ピラミッド の変化が継続している. 厚生労働省「2012 年人口動態統計月報年計の概況」によれば, 2005 年に合計特殊出生率が 過去最低の 1.26 になって以来, やや上昇傾向にあるものの昨年度でも 1.41 にとどまり, 諸外国の中でも低い国のひ とつになっている.

日本小児総合医療施設協議会に属する独立型小児病院のひとつである長野県立こども病院では, この少子化の影 響が日常の診療にどのような影響を持つのか, 注視してきたが, 本稿ではこの点に関して考察してみたい.

長野県では, 15 歳未満の人口(年少人口) は平成 5 年には 36.6 万人であったが, 平成 24 年には 28.7 万人にまでに 減少した (減少率 $22 \%$ )。 また, 出生数は当院が開設された平成 5 年には 2.2 万人であったが, 平成 24 年には 1.7 万 人までに減少した (減少率 $23 \%$ )。この間, こども病院の外来, 入院をあわせた延べ患者数は, 病棟や診療科の増設に よる影響もあるが, コンスタントに増加し, 平成 24 年には約 10.5 万人を数えた (Fig. 1).

このように, 長野県の人口統計と, こども病院の病院統計をみると, 少子化による年少人口や出生数の減少にもか かわらず, 長野県で唯一の小児専門病院である当院の患者数は, 増加している事実がわかる. 当院では, 新年度, 新 しい病院の診療体制が整うと, 新しい病院案内のパンフレットを持って, 県内の小児周産期医療施設を廻っている. 訪問する病院は, 地域における中核となるべき総合病院で, 小児科, 産婦人科を診療科目として揭げている. しかし ながら, 上述のような少子化の影響を受け, 外来患者数と入院患者数は減少し, 病棟では独立した小児病棟を維持す ることのできている病院はわずかで, 多くの病院では内科などの成人の診療科との混合病棟になっている. 年少人

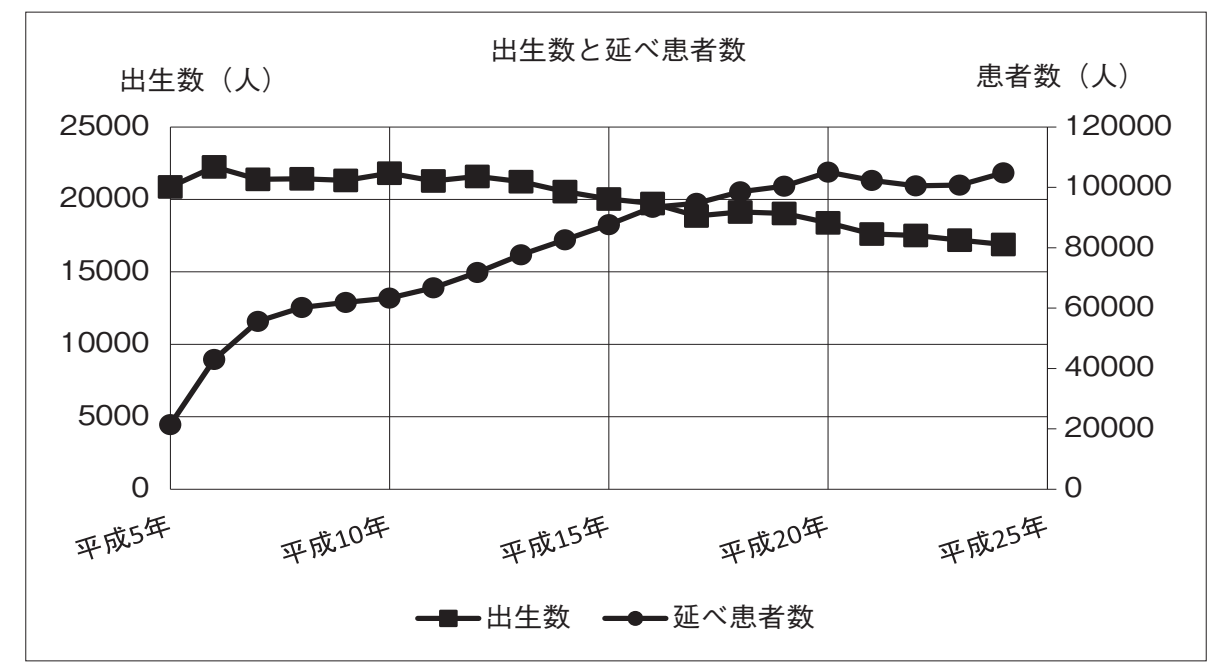

Fig. 1 長野県内の出生数と当院における延べ患者数の推移(平成 $5 \sim 24$ 年) 
口の減少に加えて, 予防接種の普及などで感染症の患者が減少し，またネフローゼなど従来では長期の入院治療を 必要としていた患者が開業医での通院治療で済むようになったことなどが, 入院患者数の減少を招いたものと考え られる。一方, 看護に関しては, 入院患者数が少ないため, 小児だけをケアする看護単位を独立して作ることができ ず，やむを得ず高齢者と小児を同時にケアする体制を取らざるを得なくなっている.こうした事態により，多くの病 院では良好な小児の療養環境を維持することが困難になっている. また, 長野県でも地方都市の医師不足が依然と して存在する。したがって, 多くの病院では, 小児医療に関わる総合力が低下し, 従来であれば診ることのできた患 者をこども病院に送らざるを得ない状況にある.

こども病院からみると, こうした事態は少子化でこどもの数が減っているにもかかわらず, 患者数が増加すること になる. 病院の経営を預かるものからすると, 喜ばしいことではあるが, 県全体の小児医療のレべルを維持するうえ では, 憂慮すべき事態である.

こども病院では, 患者数の増加に伴い, 救急患者の入り口である小児集中治療室において満床に近い状況が続き, 救急患者の受け入れが困難になる状況が常態化している。また, 心臓血管外科などの術後に集中治療室を必要とす る予定手術ができなくなる事態が生じ, 手術予定の変更を余儀なくされている.

こうした事態に対応するため, 小児集中治療室の病床数を増やす方向で検討しているが, 財政上の問題もあり, な かなか簡単には実現できる状況ではない. 近い将来, こども病院にもやってくる少子化の影響を考えると, そう簡単 には病床数を積極的に増やすという選択肢もとりづらい.

このように, 少子化にもかかわらず，こども病院への患者の集中が起きており，地方都市に立地する独立型のこど も病院の苦難は, これからも続きそうである. 